\title{
1. Austerity and the welfare state: an introduction
}

\subsection{INTRODUCTION}

Austerity and retrenchment are some of the words that have been used extensively in the public debate as well as in the academic literature on the development of welfare states during the last few years. They were first mainly used in the context of the consequences of the economic crisis in the 1970s of stagnation and inflation. Expressed among other things from the OECD publication on The Welfare State in Crisis (OECD 1981), among others. With Keynesian economic steering discredited by the then economic crisis, there was room and opportunity for other forms of economic policy, especially with a focus on monetary policy. Liberal and neoliberal understandings gained weight and it has even been argued that welfare states were in times of permanent austerity (Pierson 2002). This is in line with the debate on the legitimacy of the welfare states, including level of benefits and whether or not to support the middle class (Oorschot and Roosma 2015; Roosma et al. 2017), and questioning the legitimacy of spending as a policy strategy as it is easier to make cuts if the welfare state does not have a sufficiently high degree of support among the population (for this, read voters).

Crisis in welfare states has been argued to be caused by a wide range, albeit often very different kinds, of reasons, such as change in demography, technology, globalization, migration, legitimacy, ability to finance and so on. The financial crises from 2009 onwards are thereby just the latest in a series of pressures on welfare states. Arguments were put forward that, in order to reduce governments' budget deficit and, in the longer run, reduce debt, countries should reduce public spending. These crises and ongoing challenges can be one possible explanation for the fact that arguments and claims about crisis and cuts have formed a significant part of the literature on the development of welfare states around the globe. The 
development has further been seen as a neoliberal approach with a stronger focus on using market forces instead of the state in order to develop society.

However, the question is what is understood by austerity? Can we measure cuts in welfare states and, if so, how can this then be done? The choice of data brings with it the risk that other key aspects of societal development will then not be captured. Perhaps there is no austerity at all? Perhaps there has been limited austerity within a few selected welfare areas? Perhaps there is a difference in the development between benefits in cash and benefits in kind? Perhaps it is citizens' and voters' expectations that have not been met? Perhaps the politicians just wanted to give new types of service; however, they could only do so by reducing expenses in other areas, such as income transfers to the unemployed and those on a pension? Perhaps there has not been retrenchment but welfare states have rather been reformed (Kersbergen, Vis and Hemerijck 2014)?

The ambition of this book is to try to answer these questions from a comparative analysis of the developments, especially within the EU. The book tries to look at changes in welfare states overall, but also within the core sectors of welfare states' main spending areas. It looks at how overall expenditure and coverage (both replacement rate and conditionality) have been developing and, if possible, changes in rules for receiving benefits. Among other things, the book analyses whether there is a difference between benefit in kind and in cash. Furthermore, the book analyses whether welfare chauvinism can help in explaining the development. It is also possible that there are different degrees of change within various sub-sections of welfare states' development, including variation across welfare regimes, which are also sought to be captured in the analysis. How quality has developed is only included insofar as solid data are available to measure change herein. The use of data will be combined with existing knowledge from already published books and articles, which have been searched for using 'austerity' and 'retrenchment' as search terms. Following on from this, snowball effects from these articles combined with the author's knowledge and research about welfare states form the input to the analysis in order to answer whether there has been austerity and retrenchment, and also whether this is a permanent tendency.

There might further be a contradiction between the individual's perception of changes (e.g. a public sector worker who has a feeling 
of increased work-pressure, a recipient of services or benefits who is experiencing a reduction) and the overall macro-changes. In a way, this is a classical problem in that the understanding of changes at the micro-level and what de facto are the macro-level changes might depend on the position one is looking at changes from. So, without neglecting the individual's perception, this is included only to a more limited extent, but might be part of the explanation for varying interpretations of what has happened.

The possible challenges for welfare states and their mutual relationships, as well as factors explaining the experience of cuts, are included in the book, and this is done by looking into the development in core welfare state arenas. This first chapter discusses a few of the key issues discussed throughout the book, which sets the frame for the book. This first chapter also gives a brief overview of the contents of the entire book.

\subsection{KEY ISSUES IN THE BOOK}

The overall aim of the book is to discuss whether there has been austerity and retrenchment in developed welfare states mainly in Europe, including whether this is a permanent condition for welfare states (Pierson 2002), or whether the development more reflects a combined variation in the economic and political climate, including the possible influence of populism on welfare states development (Greve 2019). Also included is the option for a variegated change in welfare states where expansion in some sectors goes hand in hand with reduction in others. Or to put it another way: "The welfare state is not on retreating, nor has it clearly stagnated. Cutbacks were imposed on unemployment cash benefits, but family policy, healthcare, and long-term care are expanding" (Obinger and Starke 2015, 477). Despite this, it has in fact been argued that since 2008 there has been an "austerity consensus" (Edmiston, Patrick and Garthwaite 2017, 253).

The context of changes might vary across countries. The historical pathways of welfare states have also been different. Both of these are arguments for carrying out a comparative analysis, and also using the classical regime analysis (combined with a focus on Eastern and Southern Europe) (Kersbergen 2019; Aspalter 2019). This implies having a mirror to use when looking into the changes. Given the 
size of the book it is not possible to go into the detail of different countries' development, but some of the development in individual countries is referred to throughout the book. For a recent overview of the development in European welfare states, see Kuhlmann, Schubert and de Villota 2016; Blum, Kuhlmann and Schubert 2020. A further reason for using regimes as central building blocks is that the impact of liberal and neoliberal ideas has been widely discussed, and also that Southern Europe has been seen as especially hard hit (Petmesidou and Guillén 2014; Petmesidou, Pavolini and Guillén 2014; Del Pino and Ramos 2018; Sacchi 2018).

The time frame for the analysis is mainly after the financial crisis, but in most places goes further back to after the millennium as one option for understanding whether the debate is not, in fact, austerity in itself, but a slower growth in welfare spending recently compared to the historical development, and this combined with demographic changes has implied that there has not been any real increase (and in some countries real reductions) since the financial crisis. Demographic changes have for a long time been argued to be a problem for welfare states' development (Acemoglu and Restrepo 2017; Greve 2015). The combined stream of changes as a possible consequence of demographic ageing and also the financial crisis could be part of the reason why it has been argued that there has been retrenchment. There have also been debates on whether welfare states are frozen landscapes (Palier and Martin 2007). This seems not to be the case, as also argued in the aforementioned book, but still we see that adjustment, changes and whether they expand, retrench, or do something else, might also be influenced by ideas (Greve 2018; Béland and Mahon 2016; Béland 2016). Ideas can shape actors' perceptions of what is going on, so if the idea is that there has been austerity, it might be seen as such, even if no firm evidence shows it.

\subsection{OVERVIEW OF THE BOOK}

Chapter 2 presents and discusses core concepts used throughout the book - mainly with a focus on how to understand austerity and retrenchment in welfare states. Conceptualizations are important as a foundation for understanding whether and how one might measure changes and label them austerity/retrenchment. The chapter therefore presents a variety of ways in which to understand the concepts, 
as this might have an impact on our understanding of whether or not there have been strong changes in welfare states.

How to measure change is the focus of Chapter 3, where the focus is particularly on whether we can, in fact, measure changes. This is basically the dependent variable problem (Clasen and Siegel 2007), but it is also a discussion of whether changes in welfare states' development can be measured at the overall level of society. There might be more money for welfare (as a share of Gross Domestic Product, GDP), but at the same time some have experienced less money, or have a perception of areas with less money as well as a share of GDP, in the form of changes in the level or conditionality of social benefits. The classic issues of how to use fixed/current prices, cost per number of relevant citizens within an area are described, and added to which are delimitations that are used later in the book. A specific problem relates to the fact that even if resources are available within one sector, there might have been changes in how they are spent and if new types of, for example, services have to be delivered. A reduction in the level of spending might not always be a reduction in welfare available, for example, if a decline in spending on unemployment is due to an increase in the overall employment level. Thus, even a reduction in spending might or might not be an indicator of retrenchment.

The difference between interventions that have an effect now and those that have an impact at a much later date is also included. Will changes be slow, for example, because of the choice of benefits indexation techniques? Movements in pension schemes from pay-asyou-go (PAYG) to funded systems, changes in criteria for access to benefits and their consequences are presented as fundamental issues that are analysed later in the book. There is also a discussion on whether it is always possible to compare changes in rules for access to benefits and services across countries, as the interaction of other services and/or benefits varies from country to country.

Asymmetric reasons of growth in public spending are included as an example of a possible explanation for growth and, at the same time, the sense of reduction. This is because asymmetric reasons for growth in public sector spending might help in explaining that some gain and others lose; and thus those losing will see it as retrenchment, whereas those gaining will see it as a just reflection of a need to be covered.

Another core issue in the development of welfare states has been 
how to finance public sector spending, including the choice between spending and level of taxation, which is the central focus of Chapter 4. There are and may be different opinions about whether possible developments, including budget deficit and government debt management, should be financed through higher taxes and/or lower public expenditure. The discussion about this choice can have an impact on voters' perception of whether there has been a reduction in a number of policy areas. By looking into the overall financing of welfare states, this might show whether there have been decided changes in the financing that will reduce the option for future financing of welfare states, and whether a reduction in the overall level of taxes and duties implies a reason for the fact that, at least in some countries and some areas, retrenchment has been the case. The chapter also looks into the willingness to pay taxes and duties, using data from the European Social Survey related to welfare attitudes from 2008 and 2016 (latest released spring 2018) on the cost for business and benefits in order for parents to combine work and family life.

Before embarking upon a detailed analysis of development in sub-sections of the welfare states, Chapter 5 has a macro-perspective. Here, the overall development in spending is described through the use of the areas as methodologically included in the European system of integrated social protection statistics (ESSPROS) ${ }^{1}$ publications of welfare costs. Education is thus not one of the areas that are being considered. As far as possible, data back to 2000 is used, and described as a percentage of GDP and in fixed prices per inhabitant. The data is broken down into different welfare regimes for the purpose of seeing whether there are actual differences across regimes, and whether the amount of expenditure is different. The data is split up before and after the financial crisis.

The level of old age and sickness health care covered in the European Union (EU) in 2015 was close to 70 per cent ${ }^{2}$ of all expenditure. This is the reason why pensions, health care and longterm care are central policy areas for the analysis in this book.

The pension system and austerity have been analysed by many (Adascalitei 2017; Been et al. 2016; Bridgen 2019), and have also been perceived as a central and core area of welfare states, which is the focus of Chapter 6. Change in pensions has been a central policy issue in many countries, with the aim of reducing the pressure on public sector financing by using instruments such as moving from a PAYG to some kind of funded system and/or changing the eligible 
pension age so that the pension age today is later than in previous years. The chapter depicts these changes, while at the same time looks into the development in replacement rates related to pensions. Those receiving a pension are often perceived as a group of deserving people, thus if retrenchment has taken place this is in contrast to what one could expect.

In contrast, the unemployed are not seen as deserving in all countries, thus active labour market policy and unemployment benefit are the focus of Chapter 7. Further, given the historical focus on income support in case of unemployment, but also the expected possible changes in the labour market, then the unemployment benefit system might strongly influence the standard of living especially for the unemployed and others dependent on cash-benefits. The standard of living can also be influenced by the social assistance system, and since these two systems might overlap, they are discussed in the same chapter. Further, the fact that unemployment/social assistance recipients are often, in various ways, presented as less deserving makes it important to look into this.

Whereas the central focus in Chapters 6 and 7 is mainly on benefits in cash, Chapters 8 and 9 look into benefits in kind. Furthermore, the focus is on two service areas often with high support from voters. Health care is at the core in Chapter 8, as a field where it has been discussed for some time how changes in demography and the increasing cost of new types of medicine and new technology cause the risk that even if an increase in spending can be witnessed, this might still reflect a feeling of reduced welfare. Looking into money available and possible drivers of both spending and reduction in cost should help to inform about whether there has been austerity in the field. As an example, fewer days in bed at a hospital might not be austerity, but better quality. A further difficulty is that the impact of austerity on health can be both by direct changes in spending and through its possible impact on unemployment, poverty and so on (Stuckler et al. 2017); even without documenting it, Stuckler et al. argued that "austerity is a massive experiment on people in Europe" (p. 18).

Long-term care, like health care, is influenced by demographic pressure, but also changes in family life have caused pressure towards changes within the system, which is the focus in Chapter 9. This has been witnessed across countries belonging to different welfare regimes (Greve 2016). At the same time, it is an area where a reduction in the overall level of spending cannot necessarily be argued to 
be austerity, if the reduction is due, for example, to better health than in previous years and the use of interventions enabling the elderly to increase the time span in which they can take care of themselves, such as rehabilitation and the use of welfare technology. The chapter presents data on development in spending and connects them to average exit rates from the labour market and healthy life expectancy.

Even if there has not been a change in the overall level of spending or even an increase in the real level of spending, it is possible that reordering and change in spending priorities has implied austerity in another way. This might be by having an impact on poverty and inequality, in such a way that those with fewer resources have had less, whereas others have got more. This is the focus of Chapter 10. Given that a possible aspect has been that austerity has taken place mainly with regard to cash benefits and also changes in the tax system, this raises the issue about how this might have had an impact on the level of poverty and inequality. Thus, a possible contrast of the development could be that despite more money being spent on welfare, there has at the same time been an increase in inequality, with all the possible negative impacts thereof (Wilkinson and Pickett 2018, 2009). The chapter tries to link development in replacement rates and changes in the tax system with how many people are living in poverty and how the development in inequality has been brought about.

Given the different perspectives - and the reasons for the contradictions - as depicted in the previous chapters, Chapter 11 tries to explain the various ways in which to understand the development. The use of the market as a way of distributing resource has been a liberal argument for some time. A reduction in income transfers, but less so with regard to services, might be a way to understand contradictions, including who is seen as deserving and who is not. Further, the fact that this might increase is not only seen in the classical ways of measuring inequality in different positions in society. This, as part of welfare services, goes to a broader group of persons, including the middle class, so it might be that the ability to reach especially those with not as good standards of living has been reduced in order to uphold better living conditions for the middle class. Discussing the perception of working conditions and changes in the welfare states delivery are also included as important points.

Lastly, Chapter 12 answers the question: Are we in a time of permanent austerity or restricted austerity? The central tenets of 
this chapter are possible varieties of expansion or ways in which to interpret the development in European welfare states in light of changes, mainly in spending on social issues over time. This might help in answering the question of whether the literature on austerity is on the wrong track - or just does not have all the information - and that partial use of data might not tell the full story of welfare state development.

\subsection{A FEW DELIMITATIONS}

There are, as always, certain aspects that are not included in a book. A few are mentioned here - others during the presentation of the various chapters.

With regard to services, an issue such as day-care for children is not included. The main reason is that this kind of service historically has mainly been a Nordic issue. There has, however, been an increase in the support for day-care, for example, both in Germany and in the UK, so further it would not at the outset be a candidate for a policy field where one would be able to find retrenchment and austerity. In this way, this also points to the fact that even if there have been areas with a reduction in the position and role of the welfare states, there has also been an increase in others.

Also outside the scope of analysis is how those working in the welfare state perceive their working conditions. There is the possibility that they find that their working conditions have deteriorated even if there have been more resources available. The reason for this omission is that, further, it would require another set-up and other types of data, which especially in a comparative setting are very difficult to achieve.

The book does not look into whether or not there are better times than others to make interventions reducing public sector spending - such as, for example, being made by an incoming government, what has been labelled the honeymoon period where it is easier for a government to impose cut-backs (König and Wenzelburger 2017). The impact on, including the defeat of, the sitting governments is not part of the analysis (see instead Posner and Sommerfeld 2013). 


\section{NOTES}

1. See also https://ec.europa.eu/eurostat/statistics-explained/index.php/Glossary:Eu ropean_system_of_integrated_social_protection_statistics_(ESSPROS), accessed 30 March 2019.

2. Source: Social Protection Statistics, Statistics Explained, 28 November 2018.

\section{REFERENCES}

Acemoglu, D. and P. Restrepo. 2017. "Secular Stagnation? The Effect of Aging on Economic Growth in the Age of Automation." American Economic Review 107 (5): 174-179. https://doi.org/10.1257/aer.p20171101.

Adascalitei, D. 2017. "From Austerity to Austerity: The Political Economy of Public Pension Reforms in Romania and Bulgaria." Social Policy and Administration 51(3): 464 487. https://doi.org/10.1111/spol.12173.

Aspalter, C. 2019. "Ten Ideal-Typical Worlds of Welfare Regimes and Their Regime Characteristics." In B. Greve (ed.), The Routledge Handbook of the Welfare State, 2nd edn. London: Routledge, pp. 300-313.

Been, J., K. Caminada, K. Goudswaard and O. Vliet. 2016. "Public/Private Pension Mix, Income Inequality and Poverty among the Elderly in Europe: An Empirical Analysis Using New and Revised OECD Data." Social Policy \& Administration 51 (7): 1079-1100. https://doi.org/10.1111/ spol.12282.

Béland, D. 2016. "Ideas and Institutions in Social Policy Research." Social Policy \& Administration 50 (6): 734-750. https://doi.org/10.1111/spol.12258.

Béland, D. and R. Mahon. 2016. Advanced Introduction to Social Policy. Cheltenham, UK and Northampton, MA, USA: Edward Elgar Publishing.

Blum, S., J. Kuhlmann and K. Schubert. 2020. The Routledge Handbook of European Welfare Systems. London: Routledge.

Bridgen, P. 2019. "The Retrenchment of Public Pension Provision in the Liberal World of Welfare during the Age of Austerity - and Its Unexpected Reversal, 1980-2017." Social Policy and Administration 53 (1): 16-33. https://doi.org/10.1111/spol.12444.

Clasen, J. and N. Siegel. 2007. "Comparative Welfare State Analysis and the 'Dependent Variable Problem'." In J. Clasen and N. Siegel (eds), Investigating Welfare State Change. Cheltenham, UK and Northampton, MA, USA: Edward Elgar Publishing, Chapter 1, pp. 3-12.

Del Pino, E. and J. A. Ramos. 2018. "Is Welfare Retrenchment Inevitable? Scope and Drivers of Healthcare Reforms in Five Spanish Regions During the Crisis." Journal of Social Policy 47 (4): 701-720.

Edmiston, D., R. Patrick and K. Garthwaite. 2017. "Austerity, Welfare and Social Citizenship.” Social Policy and Society 16(2): 253-259. https://doi. org/10.1017/S1474746416000658.

Greve, B. 2015. Welfare and the Welfare State: Present and Future. London: Routledge. https://doi.org/10.4324/9781315761022. 
Greve, B. 2016. Long-Term Care for the Elderly in Europe: Development and Prospects. London: Routledge. https://doi.org/10.4324/9781315592947.

Greve, B. 2018. Social and Labour Market Policy: The Basics. London: Routledge. https://doi.org/10.4324/9781315150802.

Greve, B. 2019. Welfare Populism and Welfare Chauvinism. Bristol: Policy Press.

Kersbergen, K. 2019. "What are Welfare State Typologies and how are they useful, if at all?." In B. Greve (ed.), The Routledge Handbook of the Welfare State, 2nd edn. London: Routledge. Chapter 11, pp. 115-123.

Kersbergen, K., B. Vis and A. Hemerijck. 2014. "The Great Recession and Welfare State Reform: Is Retrenchment Really the Only Game Left in Town?" Social Policy \& Administration 48 (7): 883-904.

König, P. D. and G. Wenzelburger. 2017. "Honeymoon in the Crisis: A Comparative Analysis of the Strategic Timing of Austerity Policies and Their Effect on Government Popularity in Three Countries." Comparative European Politics 15 (6): 991-1015. https://doi.org/10.1057/cep.2016.1.

Kuhlmann, J., K. Schubert and P. de Villota. 2016. Recent Developments of European Welfare Systems: Multiple Challenges and Diverse Reactions. Challenges to European Welfare Systems. Heidelberg: Springer. https://doi. org/10.1007/978-3-319-07680-5_1.

Obinger, H. and P. Starke. 2015. "Welfare State Transformation. Convergence and the Rise of the Supply-Side Model." In S. Leibfried (ed.), The Oxford Handbook of Transformations of the State. Oxford: Oxford University Press, Chapter 24, pp. 465-481.

OECD. 1981. The Welfare State in Crisis. Paris: OECD.

Oorschot, W. and F. Roosma 2015. "The Social Legitimacy of Differently Targeted Benefits." Discussion Paper No. 15/11. https://core.ac.uk/down load/pdf/34633028.pdf.

Palier, B. and C. Martin. 2007. "Editorial Introduction From 'a Frozen Landscape' to Structural Reforms: The Sequential Transformation of Bismarckian Welfare Systems." Social Policy \& Administration 41 (6): 535-554. https://doi.org/10.1111/j.1467-9515.2007.00571.x.

Petmesidou, M. and A. M. Guillén. 2014. "Can the Welfare State as We Know It Survive? A View from the Crisis-Ridden South European Periphery." South European Society \& Politics 19 (3): 295-307.

Petmesidou, M., E. Pavolini and A. M. Guillén. 2014. "South European Healthcare Systems under Harsh Austerity: A Progress-Regression Mix?" South European Society and Politics 19 (3): 331-352. https://doi.org/10.10 80/13608746.2014.949994.

Pierson, P. 2002. "Coping with Permanent Austerity: Welfare State Restructuring in Affluent Democracies." Revue française de sociologie, 369-406.

Posner, P. L. and M. Sommerfeld. 2013. "The Politics of Fiscal Austerity." OECD Journal on Budgeting 13 (1): 141-174.

Roosma, F., W. van Oorschot, P. Kenneth and N. Lendvai-Bainton. 2017. "The Social Legitimacy of Welfare States in European Regions and Countries: Balancing between Popular Preferences and Evaluations.” In 
P. Kennett and N. Lendvai-Bainton (eds), Handbook of European Social Policy. Cheltenham, UK and Northampton, MA, USA: Edward Elgar Publishing, Chapter 25, pp.415-431.

Sacchi, S. 2018. "The Italian Welfare State in the Crisis: Learning to Adjust?" South European Society \& Politics 23 (1): 29-46.

Stuckler, D., A. Reeves, R. Loopstra, M. Karanikolos and M. McKee. 2017. "Austerity and Health: The Impact in the UK and Europe." European Journal of Public Health 27 (suppl_4), 18-21. https://doi.org/10.1093/ eurpub/ckx167.

Wilkinson, R. and K. Pickett 2009. The Spirit Level-Why Equality Is Better for Everyone. London: Allen Lane.

Wilkinson, R. and K. Pickett 2018. The Inner Level. How More Equal Societies Reduce Stress, Restore Sanity and Improve Everyone's WellBeing. St. Ives: Allen Lane. 